\title{
Erratum to: Fold geometry and kinematics of inversion tectonics for Kosrat anticline, northeastern Iraq
}

\author{
Manal Sh. Al-Kubaisi ${ }^{1}$ - Janan M. Barno ${ }^{1}$ - Nabeel K. Al-Azzawi ${ }^{2}$
}

Published online: 28 March 2016

(C) Saudi Society for Geosciences 2016

Erratum to: Arab J Geosci (2015) 8:9469-9480

DOI 10.1007/s12517-015-1864-x

The original version of this paper, unfortunately, contained an error.

Nabeel K. Al-Azzawi was left out in the original version. His name and affiliation is now given in this article.

The online version of the original article can be at under http://dx.doi.org/ 10.1007/s12517-015-1864-x.

Janan M. Barno

jananbarno@yahoo.com

Manal Sh. Al-Kubaisi

manalalkubaisi@yahoo.com

1 Department of Geology, College of Science, University of Baghdad, Jadiriya, Baghdad, Iraq

2 Department of Geology, College of Science, University of Mosul, Nineveh, Iraq 